\title{
New Architecture towards Ultrathin CdTe Solar Cells for High Conversion Efficiency
}

\author{
A. Teyou Ngoupo, ${ }^{1,2}$ S. Ouédraogo, ${ }^{1,2}$ F. Zougmoré, ${ }^{2}$ and J. M. B. Ndjaka \\ ${ }^{1}$ Département de Physique, Faculté des Sciences, Université de Yaoundé 1, BP 812, Yaoundé, Cameroon \\ ${ }^{2}$ Laboratoire des Matériaux et Environnement (LAME), UFR-SEA, Université de Ouagadougou, BP 7021, Ouaga 03, Burkina Faso \\ Correspondence should be addressed to A. Teyou Ngoupo; arielteyou@yahoo.fr
}

Received 24 June 2015; Accepted 30 August 2015

Academic Editor: Zhibin Yu

Copyright (c) 2015 A. Teyou Ngoupo et al. This is an open access article distributed under the Creative Commons Attribution License, which permits unrestricted use, distribution, and reproduction in any medium, provided the original work is properly cited.

\begin{abstract}
Solar Cell Capacitance Simulator in 1 Dimension (SCAPS-1D) is used to investigate the possibility of realizing ultrathin CdTe based solar cells with high and stable conversion efficiency. In the first step, we modified the conventional cell structure by substituting the CdS window layer with a CdS:O film having a wide band gap ranging from 2.42 to $3.17 \mathrm{eV}$. Thereafter, we simulated the quantum efficiency, as well as the parameters of $J-V$ characteristics, and showed how the thickness of CdS:O layer influences output parameters of Glass $/ \mathrm{SnO}_{2} / \mathrm{ZTO} / \mathrm{CdS}: \mathrm{O} / \mathrm{CdTe}_{1-x} \mathrm{~S}_{x} / \mathrm{CdTe} / \mathrm{Ni}$ reference cell. High conversion efficiency of $17.30 \%$ has been found using $\mathrm{CdTe}_{1-x} \mathrm{~S}_{x}(x=0.12)$ and CdTe layers of thickness $15 \mathrm{~nm}$ and $4 \mu \mathrm{m}$, respectively. Secondly, we introduced a BSR layer between the absorber layer and back metal contact, which led to Glass $/ \mathrm{SnO}_{2} / \mathrm{ZTO} / \mathrm{CdS}: \mathrm{O} / \mathrm{CdTe} \mathrm{e}_{1-x} \mathrm{~S}_{x} / \mathrm{CdTe} / \mathrm{BSR} / \mathrm{Ni}$ configuration. We found that a few nanometers (about $5 \mathrm{~nm}$ ) of $\mathrm{CdTe}_{1-x} \mathrm{~S}_{x}$ layer is sufficient to obtain high conversion efficiency. For BSR layer, different materials with large band gap, such as $\mathrm{ZnTe}, \mathrm{Cu}_{2} \mathrm{Te}$, and $\mathrm{p}^{+}-\mathrm{CdTe}$, have been used in order to reduce minority carrier recombination at the back contact. When ZnTe is used, high conversion efficiency of $21.65 \%$ and better stability are obtained, compared to other BSR.
\end{abstract}

\section{Introduction}

Technology of polycrystalline thin films has emerged during the last decades and has entered into direct competition with the path of multicrystalline silicon, which still dominates the market of photovoltaic. Solar cells based on polycrystalline thin films are very promising in order to achieve better efficiency/cost ratios than the other counterparts. Among the thin films cells, CdTe based solar cells are the most promising candidate for photovoltaic energy conversion because of the high potentiality to realize low cost, high efficiency, reliable, and stable solar cells [1]. CdTe is an IIVI compound semiconductor with a direct optical band gap of $\sim 1.5 \mathrm{eV}$, which is nearly optimally matched to the solar spectrum for photovoltaic (PV) energy conversion. It also has a high absorption coefficient $>5 \times 10^{5} / \mathrm{cm}$, which means that $\sim 99 \%$ of photons with energy greater than the band gap $\left(E_{g}\right)$ can be absorbed within $2 \mu \mathrm{m}$ of CdTe film [2]. The polycrystalline layers of CdTe solar cells can be synthesised using a variety of different low cost techniques such as Close-Space Sublimation (CSS), Chemical Vapor Deposition (CVD), Chemical Bath Deposition (CBD), or Sputtering [1]. However, the stability of CdTe solar cells is a complex problem which depends to a great degree on cell structure. The main stability issue for CdTe solar cells is the non-ohmic back contact and stability improvements have focused primarily on finding stable contacts without sacrificing efficiency [3]. For some years now, to improve the rear contact and reduce the recombination in the structure, a stable Back Surface Reflector (BSR) has been applied. The main role of this layer is to provide confinement for the photogenerated minority carriers and keep them within the reach of the p-n junction to be efficiently collected. This has to be accomplished without increasing the series resistance of device. Additionally, photon confinement capabilities are an interesting ancillary property for this layer [4].

Nowadays, the highest reported efficiency of $19.6 \%$ by GE Global Research [5] is still below the theoretical efficiency 


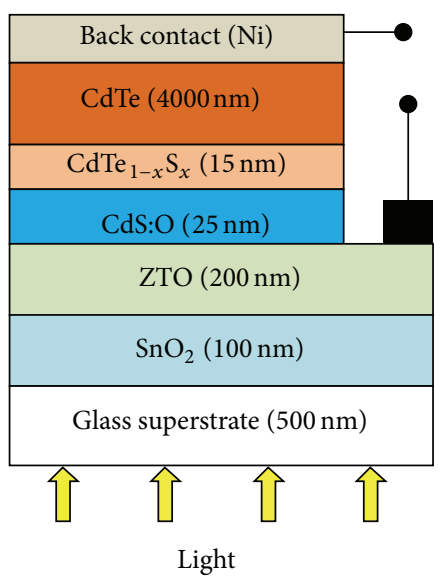

(a)

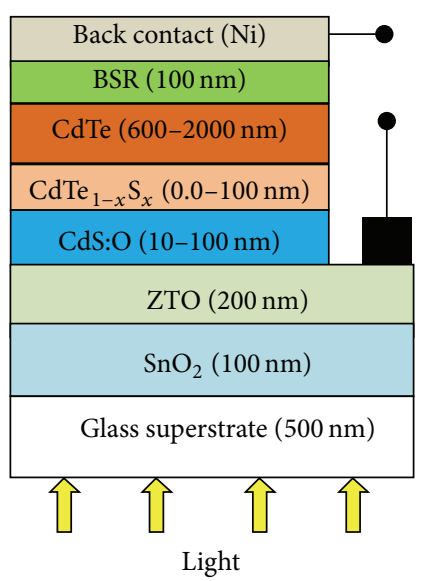

(b)

FIGURE 1: Solar cells structures: (a) reference cell; (b) our proposed cell for higher performance.

which is about $29 \%$. Thus, ultrathin heterojunction cell structure with wide band gap window layer and thinner absorber layer creates research interest. Thinning not only will save material, but will also reduce the loss of minority carriers, as well as production time and the energy needed to produce them [1].

In this work, numerical simulations of a modified structure of the conventional CdS/CdTe solar cell [6] have been performed using the SCAPS-1D program. In a first step, we replaced the window layer CdS of the conventional cell by an oxygenated nanocrystalline cadmium sulfide (CdS:O), in order to avoid the diffusion of Te from CdTe to CdS, thus preventing the formation of the solid phase $\mathrm{CdS}_{1-y} \mathrm{Te}_{y}$ at the CdS/CdTe interface. This $\mathrm{CdS}_{1-y} \mathrm{Te}_{y}$ phase damages the short wavelength optical transmission of the window layer and has a poor spectral response in this region of wavelength [7]; this could lead to reducing of performance of solar cell. In the second step, we introduced a BSR layer between the absorber layer and back metal contact in order to reduce the possible recombination at the back contact.

\section{Materials and Modeling}

2.1. Numerical Modeling. Numerical models have become indispensable tools for the design of any kind of realizable solar cell. Numerical modeling of polycrystalline thin film solar cells is an important strategy to test the viability of proposed physical explanations and to predict the effect of physical changes on cell performance [6]. Given the complex nature of CdS/CdTe thin film polycrystalline solar cells, the need for numerical modeling is apparent. Numerical simulations give insight into the mechanism of structures, thereby enabling the design of new structures with better efficiency and performance [8]. The adopted strategies to improve the performance of CdS/CdTe thin film polycrystalline solar cells have been explored using SCAPS-1D (Solar cell Capacitance Simulator in One Dimension) code, developed by Burgelman et al. [9]. The main functional aspect of SCAPS-1D is to solve the fundamental equations of carrier's transport, Poisson equation, and carrier continuity equations, in the semiconductors. SCAPS-1D does not perform calculations in the temporal domain but calculates the steady-state band diagram, recombination profile, and carrier transport in one dimension. Thus, the basic equations of semiconductors are given by [10]

$$
\begin{aligned}
\frac{\partial}{\partial x}\left(\varepsilon \frac{\partial \Psi}{\partial x}\right) & =-\frac{q}{\varepsilon_{0}}\left(p-n+N_{D}^{+}-N_{A}^{-}+\frac{\rho_{\mathrm{def}}}{q}\right), \\
-\frac{\partial J_{n}}{\partial x}-U_{n}+G & =\frac{\partial n}{\partial t}, \\
-\frac{\partial J_{p}}{\partial x}-U_{p}+G & =\frac{\partial p}{\partial t} .
\end{aligned}
$$

Figure 1 illustrates the two modified cell structures for higher conversion efficiency, which have been used in the present study. The conventional CdS/CdTe cell structure can be seen in [6].

2.2. Cell Structure and Material Parameters. In the design of a modified structure (Figure 1(b)), four new layers have been introduced: the first one is zinc stannate (ZTO) layer, introduced between the front contact and window layer in order to reduce the leakage current due to pinholes, to achieve thinner window layer, and to increase its morphology. The second one is oxygenated nanocrystalline cadmium sulfide (CdS:O) which replaces the conventional CdS window layer. The oxygen atom present in CdS:O nanocrystalline films significantly suppresses the Te interdiffusion from CdTe to the CdS film and the formation of a $\mathrm{CdS}_{1-y} \mathrm{Te}_{y}$ alloy which has a lower band gap and provides poor quantum efficiency in the short wavelength region [2]. The band gap of CdS:O film depends on the $\mathrm{O}_{2} / \mathrm{Ar}$ ratio in the film growth process; the band gap can increase from $2.42 \mathrm{eV}$ to $3.17 \mathrm{eV}$ with increasing $\mathrm{O}_{2} /$ Ar ratio [11] as shown in Table 1 . Weak thickness and large band gap of this layer increase the blue region response of the cell and reduce the surface recombination current. The third layer is a $\mathrm{CdTe}_{1-x} \mathrm{~S}_{x}(x=0.12)$ solid phase which is unintentionally and automatically developed in the CloseSpace Sublimation (CSS) film growth process. The layer 
TABLE 1: The band gap of CdS:O films with $\mathrm{O}_{2} /$ Ar ratio.

\begin{tabular}{lc}
\hline $\mathrm{O}_{2} / \mathrm{Ar}(\%)$ & Optical band gap $(\mathrm{eV})$ \\
\hline 0 & 2.42 \\
1 & 2.52 \\
2 & 2.65 \\
3 & 2.80 \\
5 & 3.17 \\
\hline
\end{tabular}

thickness depends on CSS growth time, which can be reduced in the real fabrication process [12], and the high temperature associated with the CSS. The presence of this solid phase may be important in such things as preventing shunts, maximizing the CdS-CdTe contact area and improving the CdS-CdTe interface [7]. Alloy band gap can be predicted using a simple quadratic equation [13]:

$$
\begin{aligned}
E_{g, \text { alloy }}(x)= & 1.7 x^{2}+\left[E_{g, \mathrm{Cds}: \mathrm{O}}-E_{g, \mathrm{CdTe}}-1.7\right] x \\
& +E_{g, \mathrm{CdTe}} .
\end{aligned}
$$

The last layer is the Back Surface Reflector (BSR). It is introduced between metal back contact and CdTe absorber layer, to reduce the possible recombination at the back contact and the effect of the rollover in the ultrathin CdTe solar cells. BSR, as $\mathrm{ZnTe}, \mathrm{Cu}_{2} \mathrm{Te}$, and $\mathrm{p}^{+}-\mathrm{CdTe}$ in this numerical simulation, has a wide band gap and it forms CdTe/BSR heterojunction with the absorber layer. This layer can contribute to increasing of $V_{\mathrm{OC}}$ and could also contribute in the carrier enhancement by reflecting the carriers towards the main junction [14].

All material parameters used in this work are listed in Table 2; these values have been taken within the literature and some are the reasonable estimation. The variable material parameters regarding the structure can be the layer thickness, doping concentration, ratio of $\mathrm{CdTe}_{1-x} \mathrm{~S}_{x}$ mixing, band gap, and so forth.

\section{Results and Discussion}

SCAPS-1D simulations have been performed to find the appropriate and stable structure of nano-CdS:O/CdTe solar cell using a number of variable parameters related to the electrical and optical properties of nano-CdS:O and BSR layers, in order to improve the performances of the conventional CdS/CdTe solar cell described in [6].

\subsection{Reference Cell Simulation}

3.1.1. Comparison with a Conventional Solar Cell. In this section, the results of calculations performed using the device cell structure of Figure 1(a) as starting point are compared to simulations done with a conventional cell. Figure 2 shows a superposition of $J-V$ curve of both cells. The resulting performance parameters of the open-circuit voltage $\left(V_{\mathrm{OC}}\right)$, shortcircuit current density $\left(J_{\mathrm{sc}}\right)$, fill factor $(\mathrm{FF})$, and efficiency are determined and are shown in Table 3.

The performance parameters of our reference cell are slightly higher than those of conventional cell (Table 3). This

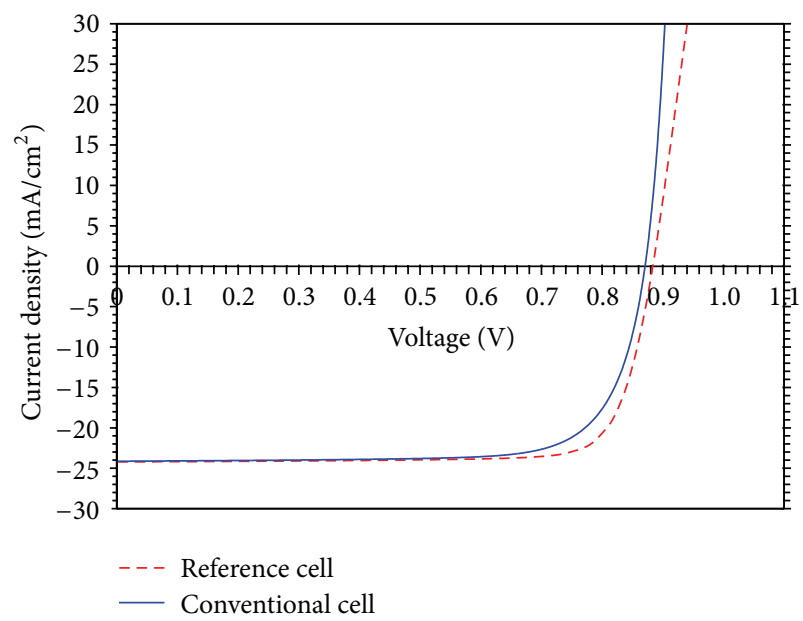

Figure 2: Comparison between the photocurrent density-voltage $(J-V)$ curves for a conventional cell (blue line) and a reference cell (red line).

result is attributed to the three basic layers that have been introduced, mainly to ZTO buffer layer, which has a high resistivity, avoids pinholes effect, and increases morphology of window layer, what reduces series resistance and increases fill factor. For the comparison, CdTe, $\mathrm{CdTe}_{1-x} \mathrm{~S}_{x}(x=$ 0.12 ), and nano-CdS:O layers thicknesses in our reference cell are, respectively, $4 \mu \mathrm{m}, 15 \mathrm{~nm}$, and $25 \mathrm{~nm}$. CdTe doping concentration adopted is $5.5 \times 10^{14} \mathrm{~cm}^{-3}$.

As mentioned above, the main role of ZTO buffer layer, with high resistivity, is to achieve thinner window layer and increase its morphology, what can significantly improve the blue response of the solar cell.

3.1.2. Effect of the Nano-CdS:O Layer Thickness. The dependency of cell performance on the nano-CdS:O layer thickness from 10 to $200 \mathrm{~nm}$ has been simulated, in order to achieve thinner window layer. CdTe, $\mathrm{CdTe}_{1-x} \mathrm{~S}_{x}(x=0.12)$, ZTO, and $\mathrm{SnO}_{2}$ layers thicknesses are, respectively, $4 \mu \mathrm{m}, 15 \mathrm{~nm}$, $200 \mathrm{~nm}$, and $100 \mathrm{~nm}$ in this case, all others parameters of the cell remaining constant.

When the nano-CdS:O thickness was reduced to explore thinner nano-CdS:O layer, the absorption loss in the blue region due to thick CdS:O layer also reduced, which improved mainly $J_{s c}$ and cell conversion efficiency $[1,8]$. The effect of the reduction of nano-CdS:O layer from 200 to $10 \mathrm{~nm}$ is shown in Figure 3. Below $500 \mathrm{~nm}$ of wavelength, quantum efficiency of cell is much more affected by increasing of the nano-CdS:O layer thickness (Figure 3(b)). Some photons cause the process of vibration of atoms around their equilibrium position. This phenomenon does not contribute to the photocurrent and raises consequently the losses in the structure of the solar cell. Therefore, it would lead to decrease in the photons which have reached the absorber layer and contribute to photovoltaic conversion. A decrease in the number of photons at the absorber layer would decrease the quantum efficiency of the solar cell [15].

When the nano-CdS:O layer is thinner, photocurrent increases slightly and conversion efficiency also increases. In 
TABLE 2: Material parameters used in the numerical analysis for the nano-CdS:O/CdTe cell.

\begin{tabular}{|c|c|c|c|c|c|c|}
\hline \multirow{2}{*}{ Parameter } & \multicolumn{6}{|c|}{ Material layer } \\
\hline & $\mathrm{n}-\mathrm{SnO}_{2}$ & n-ZTO & n-CdS:O & $\mathrm{p}-\mathrm{CdTe}_{1-x} \mathrm{~S}_{x}(x=0.12)$ & p-CdTe & $\mathrm{ZnTe} / \mathrm{Cu}_{2} \mathrm{Te} / \mathrm{p}^{+}-\mathrm{CdTe}$ \\
\hline Thickness $(\mu \mathrm{m})$ & 0.1 & 0.2 & $0.01-0.1$ & $0.0-0.3$ & $0.6-2$ & 0.1 \\
\hline Dielectric constant & 9.0 & 9.0 & 10.0 & 9.4 & 9.4 & $14 / 10 / 10$ \\
\hline $\begin{array}{l}\text { Electron mobility, } \mu_{n} \\
\left(\mathrm{~cm}^{2} / \mathrm{Vs}\right)\end{array}$ & 100 & 52 & 100 & 320 & 320 & $100 / 500 / 110$ \\
\hline $\begin{array}{l}\text { Hole mobility, } \mu_{p} \\
\left(\mathrm{~cm}^{2} / \mathrm{Vs}\right)\end{array}$ & 25 & 3 & 25 & 40 & 40 & $10 / 100 / 70$ \\
\hline $\begin{array}{l}\text { Electron and hole } \\
\text { concentration, } n, p \\
\left(\mathrm{~cm}^{-3}\right)\end{array}$ & $10^{17}$ & $10^{19}$ & $1.1 \times 10^{18}$ & $2 \times 10^{14}$ & $10^{16} / 10^{16} / 10^{17}$ & $7.5 \times 10^{19} / 10^{21} / 7.9 \times 10^{19}$ \\
\hline Band gap, $E_{g}(\mathrm{eV})$ & 3.60 & 3.35 & 2.80 & 1.47 & 1.50 & $2.26 / 1.18 / 1.45$ \\
\hline $\begin{array}{l}\text { Density of states at } \\
\text { conduction band, } N_{c} \\
\left(\mathrm{~cm}^{-3}\right)\end{array}$ & $2.2 \times 10^{18}$ & $2.1 \times 10^{18}$ & $2.2 \times 10^{18}$ & $7.9 \times 10^{17}$ & $7.9 \times 10^{17}$ & 7.8/7.8/7.9 $\left(\times 10^{17}\right)$ \\
\hline $\begin{array}{l}\text { Density of states at } \\
\text { valance band, } N_{v}\left(\mathrm{~cm}^{-3}\right)\end{array}$ & $1.8 \times 10^{19}$ & $1.5 \times 10^{19}$ & $1.8 \times 10^{19}$ & $1.8 \times 10^{19}$ & $1.8 \times 10^{19}$ & 1.6/1.6/1.8 $\left(\times 10^{19}\right)$ \\
\hline Electron affinity, $\chi(\mathrm{eV})$ & 4.55 & 4.50 & 4.50 & 4.26 & 4.26 & $3.65 / 4.20 / 4.28$ \\
\hline
\end{tabular}

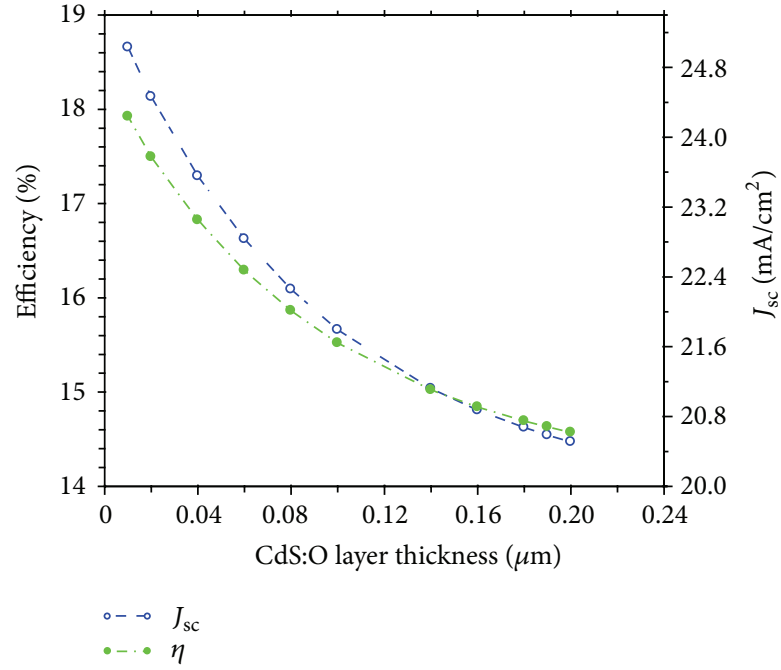

(a)

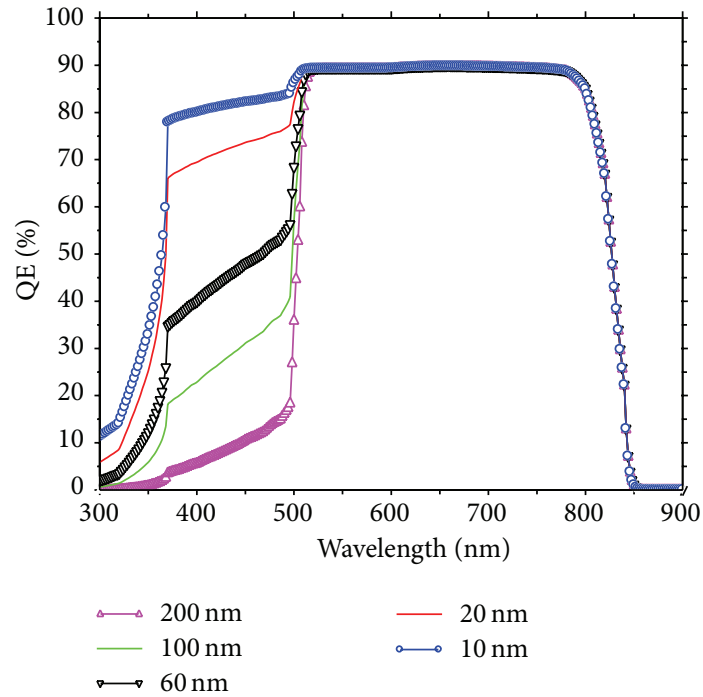

(b)

FIGURE 3: Effect of CdS:O thickness on $J_{\text {sc }}$, efficiency, and QE of solar cell.

TABLE 3: Comparison of both cells.

\begin{tabular}{lcccc}
\hline Cell & $V_{\mathrm{OC}}(\mathrm{V})$ & $J_{\mathrm{sc}}\left(\mathrm{mA} / \mathrm{cm}^{2}\right)$ & $\mathrm{FF}(\%)$ & Eff. $(\%)$ \\
\hline Conventional & 0.871 & 24.132 & 76.14 & 16 \\
Reference & 0.883 & 24.216 & 80.91 & 17.3 \\
\hline
\end{tabular}

order to investigate ultrathin cell for high conversion, the thickness of nano-CdS:O layer has been set to $25 \mathrm{~nm}$.

3.1.3. Effect of the CdTe Layer Thickness. Theoretically, the minimum thickness required for CdTe film to absorb $99 \%$ of the incident photons with energy greater than $E_{g}$ is approximately 1-2 $\mu \mathrm{m}$. Previously, almost all the high efficiency CdTe solar cells were fabricated with more than $5 \mu \mathrm{m}$ thick CdTe absorber layer [1]. However, further numerical simulation was done to reduce the thickness of the cell, aiming to reduce the amount materials used, as well as time and cost production. Cell thickness reduction not only would be useful to reduce the material cost and time in the production process, but also could lead to better solar cell properties by reducing recombination in the bulk. However, control of the film growth and recrystallization due to postdeposition treatment is necessary to obtain thin films which are compact and free of pinholes [1]. In Figure 4, at the lower value of CdTe thickness, $J_{\text {sc }}$ decrease sharply because the minority carrier diffusion length is critically shorter but FF shows a little increased value, due to the reduction of bulk resistance 


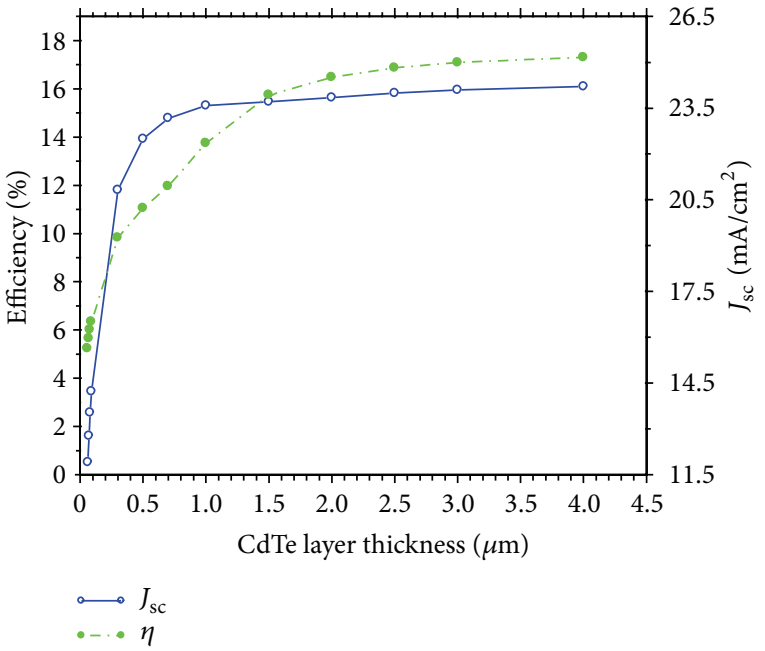

(a)

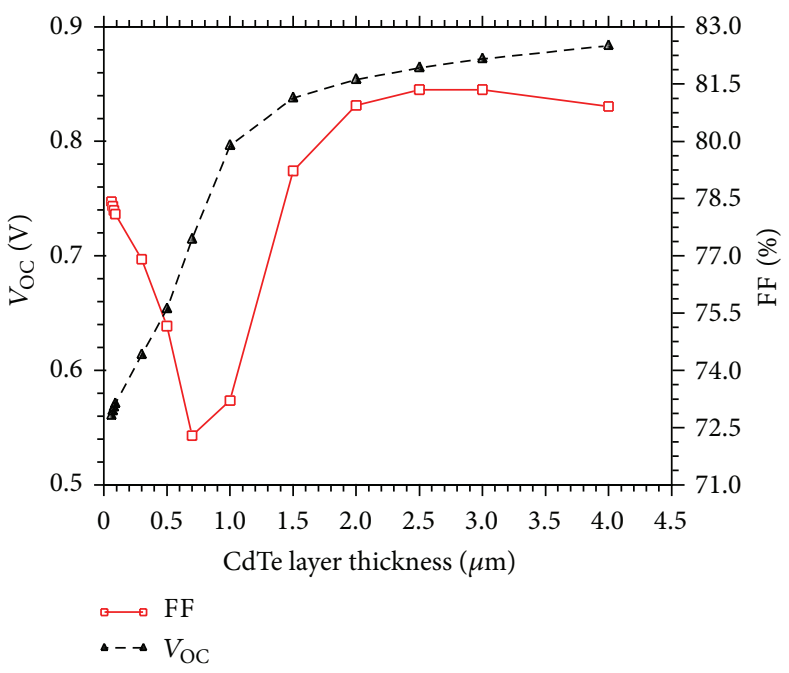

(b)

Figure 4: Effect of CdTe thickness on FF, $V_{\mathrm{OC}}, J_{\mathrm{sc}}$, and efficiency of solar cell.

TABLE 4: Output parameters of different cells with BSR.

\begin{tabular}{|c|c|c|c|c|}
\hline Different cell structures & $V_{\mathrm{OC}}(\mathrm{V})$ & $J_{\mathrm{sc}}\left(\mathrm{mA} / \mathrm{cm}^{2}\right)$ & $\mathrm{FF}(\%)$ & Eff. $(\%)$ \\
\hline Glass/SnO $2 / \mathrm{ZTO} / \mathrm{CdS}: \mathrm{O} / \mathrm{CdTe}_{1-x} \mathrm{~S}_{x} / \mathrm{CdTe} / \mathrm{Ni}$ & 0.883 & 24.216 & 80.91 & 17.30 \\
\hline Glass/SnO $2 / \mathrm{ZTO} / \mathrm{CdS}: \mathrm{O} / \mathrm{CdTe}_{1-x} \mathrm{~S}_{x} / \mathrm{CdTe} / \mathrm{Cu}_{2} \mathrm{Te} / \mathrm{Ni}$ & 1.021 & 22.672 & 85.52 & 19.79 \\
\hline Glass/SnO ${ }_{2} / \mathrm{ZTO} / \mathrm{CdS}: \mathrm{O} / \mathrm{CdTe}_{1-x} \mathrm{~S}_{x} / \mathrm{CdTe} / \mathrm{p}^{+}-\mathrm{CdTe} / \mathrm{Ni}$ & 1.056 & 23.923 & 86.04 & 21.73 \\
\hline $\mathrm{Glass}_{\mathrm{SnO}} / \mathrm{ZTO} / \mathrm{CdS}: \mathrm{O} / \mathrm{CdTe}_{1-x} \mathrm{~S}_{x} / \mathrm{CdTe} / \mathrm{ZnTe} / \mathrm{Ni}$ & 1.072 & 25.860 & 77.89 & 21.59 \\
\hline
\end{tabular}

for CdTe material. These results are in a good agreement with those of the literature $[8,16]$. Our result showed that, above $2 \mu \mathrm{m}$, the cell output parameters are no longer affected; they are almost constant. This result is obtained with layers thicknesses of $\mathrm{CdTe}_{1-x} \mathrm{~S}_{x}(x=0.12), \mathrm{CdS}: \mathrm{O}, \mathrm{ZTO}$, and $\mathrm{SnO}_{2}$ set to $15 \mathrm{~nm}, 25 \mathrm{~nm}, 200 \mathrm{~nm}$, and $100 \mathrm{~nm}$, respectively, and all others parameters of the cell remaining constant.

In order to investigate high conversion efficiency with thin $\mathrm{CdTe}$, the value $1.5 \mu \mathrm{m}$ of layer thickness has been chosen and, below this value, conversion efficiency of cell decreases rapidly. Having a thin CdTe layer, while maintaining higher conversion efficiency, is not possible for our reference cell. However, there are possibilities of increasing $V_{\mathrm{OC}}, J_{\mathrm{sc}}$, and FF below CdTe thickness of $1.5 \mu \mathrm{m}$, while having improved efficiency. In order to attain this goal, the reference structure has been modified by inserting the BSR [16] between absorber layer and metal back contact.

3.2. Proposed Ultrathin Structure for High Conversion. Numerical analysis with SCAPS-1D has been done with the proposed ultrathin cell structure (Figure 1(b)), aiming to investigate the effect of different BSR material on performance of solar cell.

3.2.1. BSR Layer. Numerical analysis has been carried out to determine the effect of different BSR material on performance of cell. The layers thicknesses of BSR, CdTe, CdTe $\mathrm{C}_{1-x} \mathrm{~S}_{x}(x=$ 0.12 ), CdS:O, ZTO, and $\mathrm{SnO}_{2}$ are set to $100 \mathrm{~nm}, 1.5 \mu \mathrm{m}$, $15 \mathrm{~nm}, 25 \mathrm{~nm}, 200 \mathrm{~nm}$, and $100 \mathrm{~nm}$, respectively, and all others

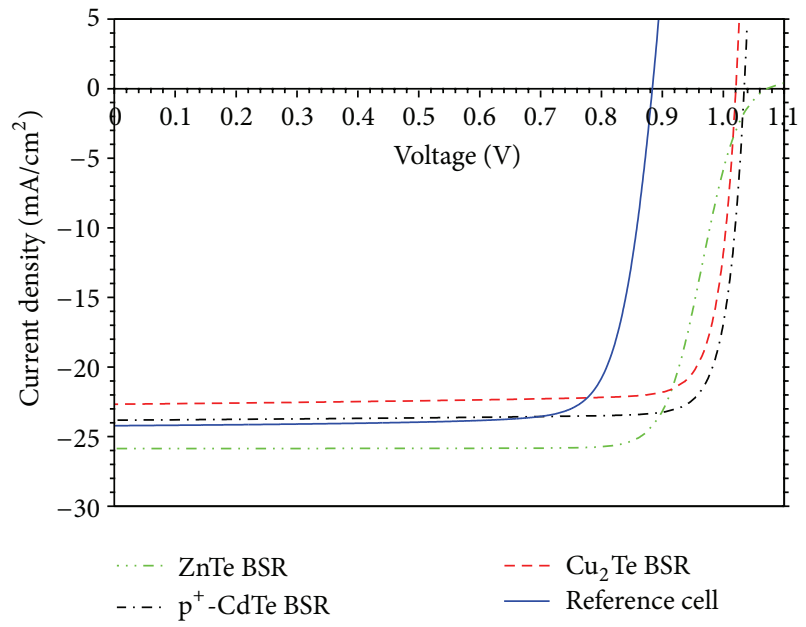

FIgURE 5: $I-V$ curve of reference cell and modified cell.

parameters of the cell remain constant. As mentioned above, BSR layer is considered to be beneficial to the performance of CdTe cells. A thin layer of BSR causes the depletion region of the Schottky barrier contact to be narrow, where majority holes carriers can tunnel through minimizing the loss. This layer may also add an additional absorption layer to the structure, which will increase the photogenerated carriers [17]. The BSR material has great influence in $J-V$ characteristics of the cell, as shown in Figure 5. Table 4 shows that the introduction 


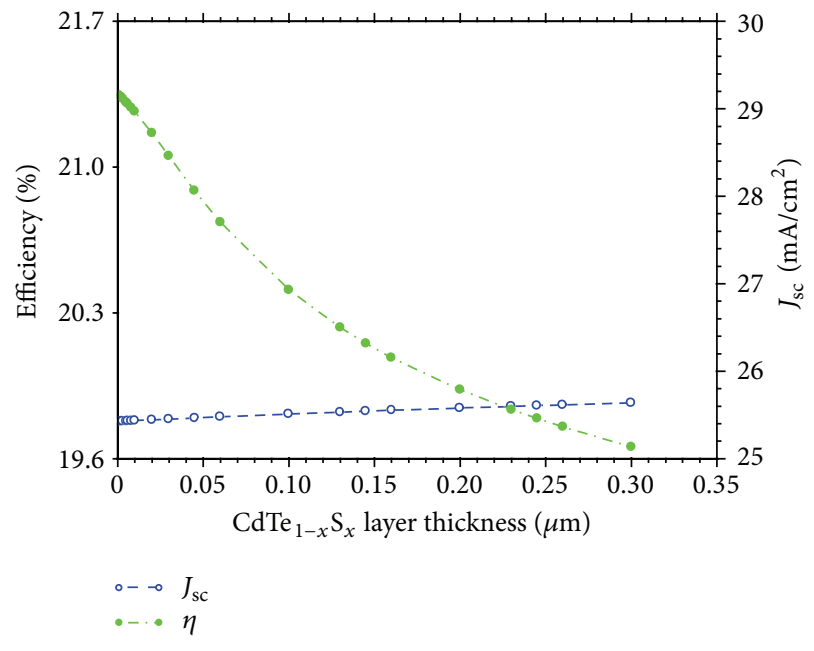

(a)

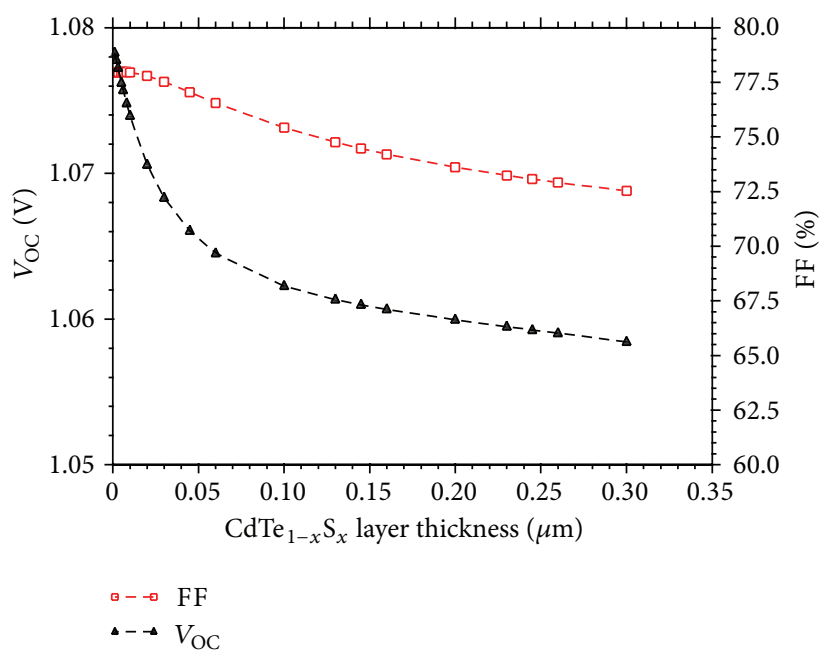

(b)

FIGURE 6: Effect of $\mathrm{CdTe}_{1-x} \mathrm{~S}_{x}$ thickness on $J_{\mathrm{sc}}, V_{\mathrm{OC}}$, FF, and efficiency of modified solar cell.

of BSR layer leads to better performance than reference cell, whatever be the nature of the BSR material. Indeed, BSR causes the reflection of minority carriers towards the main junction and reduces their recombination at the back contact [16]; thus, both open-circuit voltage and short-circuit current can be increased.

As can be seen in Figure 5, the cell structure with BSR shows higher $V_{\mathrm{OC}}$ than the cell without BSR. The larger band gap of BSR contributes to increasing of $V_{\mathrm{OC}}$ as the absorber layer is thin $(<2 \mu \mathrm{m})$. The cell with $\mathrm{ZnTe}$ shows higher $V_{\mathrm{OC}}$ and $J_{\text {sc }}$ but poor FF; this might be attributed to the presence of a back electron barrier at the rear of the absorber which reduces the minority carrier recombination. All the BSR effectively reflect back the minority carriers; an appropriated barrier height denoted by $\Phi_{e}$ in the conduction band near the back surface, often referred to as an electron reflector barrier, is critical to reduce voltage-limiting recombination at the back surface $[8,18]$. Due to this electron reflector barrier, cells with BSR have shown higher $V_{\mathrm{OC}}$ as shown in Table 4 . Using ZnTe as BSR shows more significance in term of improvement of $V_{\mathrm{OC}}$ and $J_{\mathrm{sc}}$ than $\mathrm{Cu}_{2} \mathrm{Te}$ and $\mathrm{p}^{+}$-CdTe. It seems that, with a modest electron reflector barrier $(0.2 \mathrm{eV})$, the electrons are reflected back towards the front contact. A potential difficulty, however, is that any recombination at the CdTe-BSR interface will compromise the advantage of keeping electrons away from the metal interface [18]. Cell with ZnTe shows poor FF because of the higher series resistance added by the bulk resistance of the higher band gap and lower dielectric property of the ZnTe material $[8,16]$.

The introduction of BSR layer leads to better performance than reference cell, whatever the nature of the BSR material is. The use of $\mathrm{p}^{+}$-CdTe as BSR layer permits getting an efficiency of conversion of $21.73 \%$ for the modified cell.

3.2.2. $C d T e_{1-x} S_{x}$ Layer $(x=0.12)$. In order to investigate the effect of $\mathrm{CdTe}_{1-x} \mathrm{~S}_{x}$ layer thickness on the output parameters of the modified cell for high conversion, the properties of the different layers are kept constant, while varying the thickness of this layer from $1 \mathrm{~nm}$ to $300 \mathrm{~nm}$ in this numerical simulation. As mentioned above, this thickness depends on CloseSpace Sublimation (CSS) growth time process. The results obtained from SCAPS-1D with ZnTe as BSR are shown in Figure 6.

It can be observed that the solar cell output parameters are strongly dependent on $\mathrm{CdTe}_{1-x} \mathrm{~S}_{x}$ layer thickness; but $J_{\text {sc }}$ is not much affected. The incorporation of $\mathrm{S}$ into CdTe layer influences the junction transport properties, by increasing absorbed photons and carrier collection in the long wavelengths of the spectrum which contribute to the photocurrent and reducing of interface state density in the $\mathrm{CdS} / \mathrm{CdTe}$ interface for thin $\mathrm{CdTe}_{1-x} \mathrm{~S}_{x}$ layer. But, for a thick $\mathrm{CdTe}_{1-x} \mathrm{~S}_{x}$ layer, efficiency shows a decreasing trend; this may be attributed to the recombination in this layer and at the CdS/CdTe interface. For $1 \mathrm{~nm}$ of the $\mathrm{CdTe}_{1-x} \mathrm{~S}_{x}$ layer, we obtain a highest efficiency of $21.72 \%$. In order to take the fabrication challenges, the value of $10 \mathrm{~nm}$ of the $\mathrm{CdTe}_{1-x} \mathrm{~S}_{x}$ layer thickness was chosen with an efficiency of $21.65 \%$.

The improvement of efficiency of the modified cell structure with ZnTe as a BSR is mainly due to improvement of $V_{\mathrm{OC}}$ and FF, but again $J_{\mathrm{sc}}$ is reduced slightly [12], when $\mathrm{CdTe}_{1-x} \mathrm{~S}_{x}$ layer thickness is reduced.

3.2.3. Electric Parameters of Ultrathin Cell Structure and Conventional Cell. To show that the new structure, with ZnTe, $\mathrm{CdTe}_{1-x} \mathrm{~S}_{x}(x=0.12)$, and nano-CdS:O layers thicknesses of $100 \mathrm{~nm}, 10 \mathrm{~nm}$, and $25 \mathrm{~nm}$, respectively, is more economic in raw material as mentioned in the introduction of this work, we are going to compare the evolution of the electric parameters of this structure to those of a conventional solar cell, when the CdTe layer thickness varies (Figure 7) and all others parameters of the cells remain constant.

It can be observed in Figure 7 that the expected higher conversion efficiency for the ultrathin structure, as compared to the conventional solar cell, is a result mainly of the higher open-circuit voltage and short-circuit current density, as the CdTe layer thickness is reduced. This result is due both to 


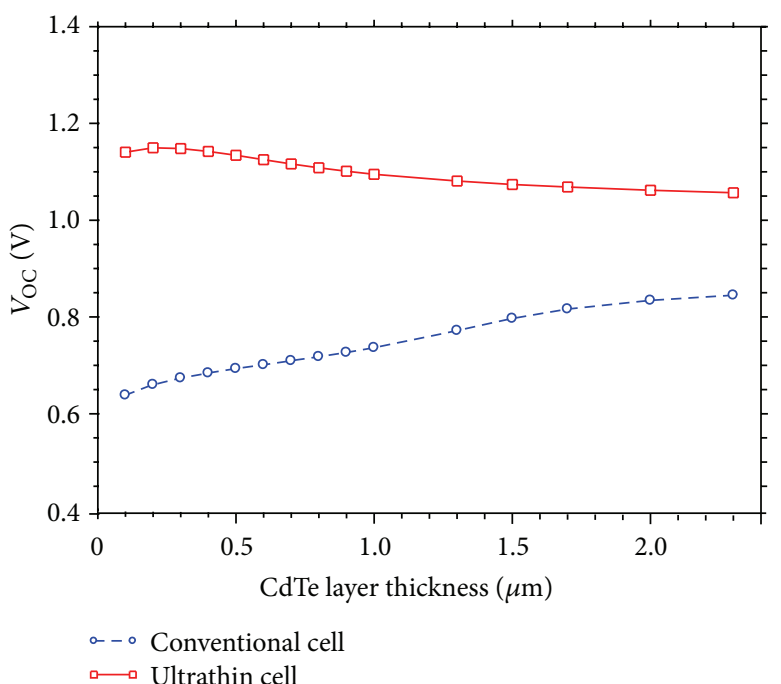

(a)

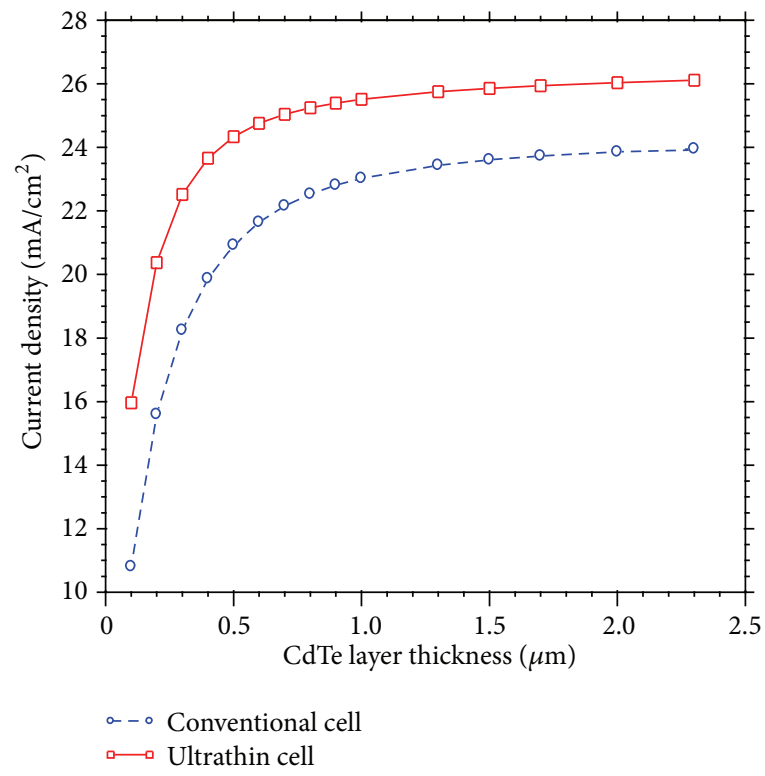

(c)

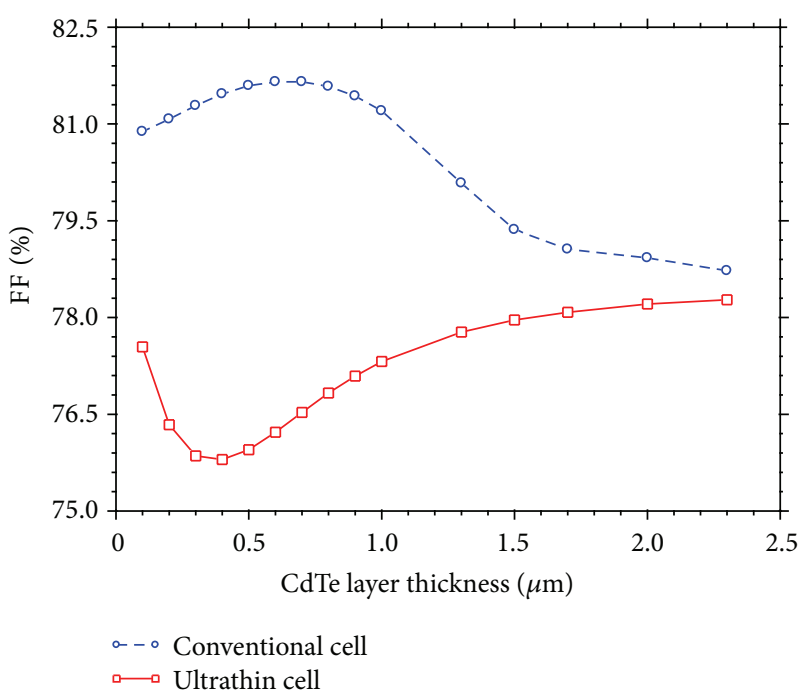

(b)

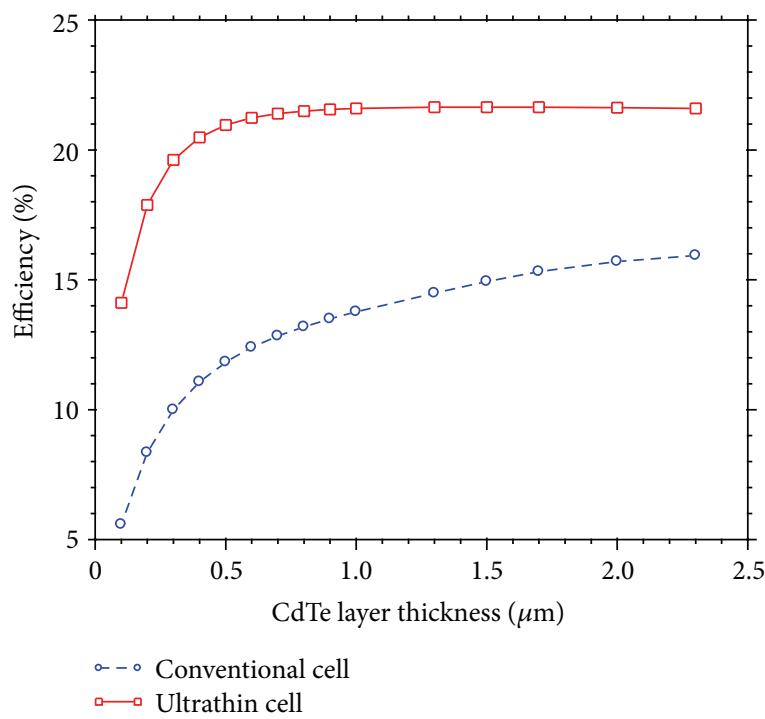

(d)

Figure 7: Comparison of electrical parameters $\left(V_{\mathrm{OC}}, \mathrm{FF}, J_{\mathrm{sc}}\right.$, and efficiency) of ultrathin structure and conventional solar cell as a function of CdTe absorber thickness.

the back surface and to the built-in electric field in the CdTe layer, as a consequence of the back ZnTe layer in the former case [19]. For CdTe layer thickness which equals $1.5 \mu \mathrm{m}$, the gain of efficiency for the ultrathin structure, as compared to the conventional solar cell, is around $6.72 \%$. This gain is mainly attributed to the electrons reflected at the CdTe/ZnTe interface (due to the conduction-band discontinuity) and collected with a higher probability at the main junction. The poor FF (Figure 7(b)) of the ultrathin structure is due to the high resistive ZTO buffer layer and the higher series resistance added by the bulk resistance of the higher band gap and lower dielectric property of the ZnTe material. FF shows a little increased value, in the case of the conventional cell, due to the reduction of bulk resistance for CdTe material.
Finally, the ultrathin cell is more economic in raw material (reduction of solar cell cost) and has the higher conversion efficiency than the conventional solar cell, but poor FF due to the high resistivity of buffer layer and the higher series resistance added by the bulk resistance of the ZnTe BSR layer.

3.2.4. Stability of Cell without and with BSR. The stability of the ultrathin $\mathrm{CdS}: \mathrm{O} / \mathrm{CdTe}_{1-x} \mathrm{~S}_{x} / \mathrm{CdTe}$ proposed cell at higher operating temperature has been investigated. In real cases, operating temperature plays a very important role which affects the performance and stability of the cells. At higher operating temperature, cell layers parameters such as the effective density of states, absorption coefficients, electron 


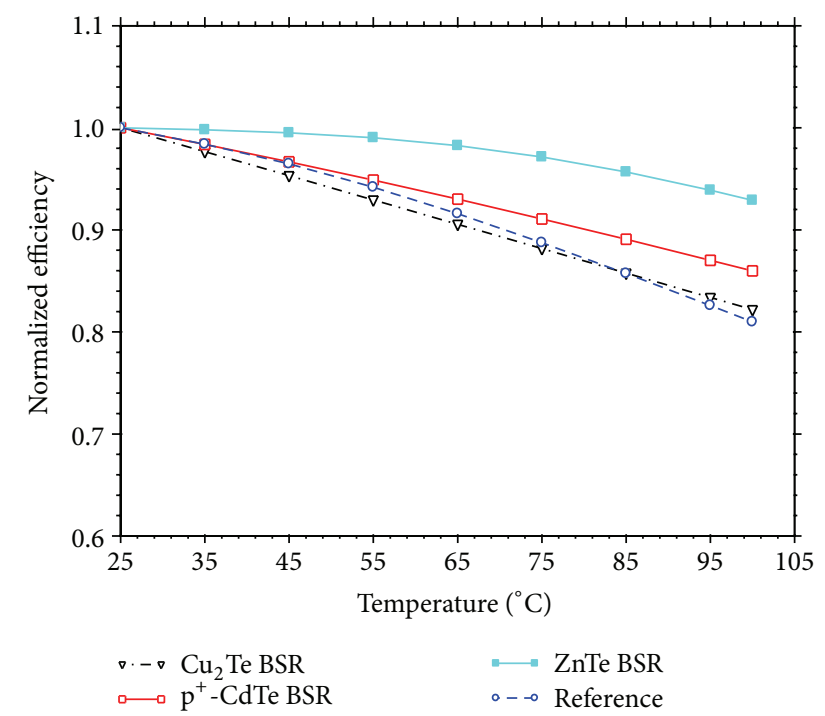

FIGURE 8: Effect of operating temperature on normalized efficiency of reference and modified cell structures.

and hole mobility, electron and hole thermal velocity, carrier concentrations, and band gaps of the materials are affected [1]. An investigation was conducted using SCAPS-1D at operating temperature which ranged from $25^{\circ} \mathrm{C}$ to $100^{\circ} \mathrm{C}$ for the proposed cells. The results obtained from SCAPS-1D simulation are shown in Figure 8.

The effect of temperature can be measured by a term named temperature coefficient (TC), which can be defined as the change of power of solar cell for increase or decrease of operating temperature per degree centigrade [4]. This TC indicates the degree of stability of the cell at higher operating temperature or in stressed conditions. It is evident from Figure 8 that the conversion efficiency linearly decreases with the increase of operating temperature. The temperature coefficient of reference cell is found to be $-0.27 \% /{ }^{\circ} \mathrm{C}$. Cells with $\mathrm{p}^{+}$-CdTe and $\mathrm{Cu}_{2} \mathrm{Te}$ BSR layers slightly follow the same trends with a temperature coefficient of $-0.19 \% /{ }^{\circ} \mathrm{C}$ and $-0.24 \% /{ }^{\circ} \mathrm{C}$, respectively. The cell with ZnTe BSR shows different trend than the previous cells and its efficiency remains almost unchanged when the operating temperature is in the range from $25^{\circ} \mathrm{C}$ to $55^{\circ} \mathrm{C}$ and then it decreases with a $\mathrm{TC}$ of $-0.15 \% /{ }^{\circ} \mathrm{C}$. Therefore, the cell with ZnTe BSR layer shows a better stability against temperature than others modified cells.

A modified cell with higher open-circuit voltage and band gap is less affected by temperature; it is the case of the

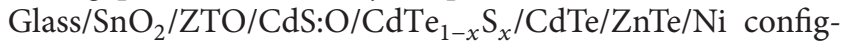
uration which presents a better stability against temperature.

\section{Conclusion}

Numerical analyses of CdTe solar cells have been performed in order to examine the potential improvement. Four different structures have been analyzed by using SCAPS-1D package, in order to minimize some issues related to conventional
$\mathrm{SnO}_{2} / \mathrm{CdS} / \mathrm{CdTe}$ cells. The basic issue here was to determine the effects of nano-CdS:O window and BSR layers on the output parameters of CdTe solar cell. Due to the high band gap and suppression of the Te interdiffusion from CdTe to CdS film, that is, the formation of $\mathrm{CdS}_{1-y} \mathrm{Te}_{y}$ alloy at the $\mathrm{p}-\mathrm{n}$ junction, incorporating nano-CdS: $\mathrm{O}$ as a window layer into the conventional CdTe solar cell improves cell performance compared to the standard CdS window layer. The band gap of nano-CdS:O layer increases with an increase of oxygen content and decrease of grain size. The presence of $\mathrm{CdTe}_{1-x} \mathrm{~S}_{x}$ solid phase at the interface of $\mathrm{p}-\mathrm{n}$ junction which reduces interface state density is also beneficial to the solar cell and extends spectral response to higher wavelength. An efficiency of $17.30 \%\left(V_{\mathrm{OC}}=0.883 \mathrm{~V}, J_{\mathrm{sc}}=24.216 \mathrm{~mA} / \mathrm{cm}^{2}\right.$, and $\mathrm{FF}=80.91 \%)$ was obtained from numerical analysis of reference cell (Glass/SnO $/ 2 \mathrm{ZTO} / \mathrm{CdS}: \mathrm{O} / \mathrm{CdTe}_{1-x} \mathrm{~S}_{x} / \mathrm{CdTe} / \mathrm{Ni}$ ). Moreover, the overall performance of cell was affected by incorporating different BSR layers. This new configuration (Glass/SnO $2 / \mathrm{ZTO} / \mathrm{CdS}: \mathrm{O} / \mathrm{CdTe}_{1-x} \mathrm{~S}_{x} / \mathrm{CdTe} / \mathrm{BSR} / \mathrm{Ni}$ ) avoids the effect of such recombination at the back contact, rollover, by producing mirror for minority carriers and by reducing the Schottky barrier height. In this configuration, reducing $\mathrm{CdTe}_{1-x} \mathrm{~S}_{x}$ layer thickness to a few nanometers increases conversion efficiency of the cell. A modified cell with higher open-circuit voltage and band gap is less affected by temperature. A cell with ZnTe as BSR layer present a better stability in the high operating temperature with a temperature coefficient of $-0.15 \% /{ }^{\circ} \mathrm{C}$. ZnTe BSR layer also presents poor FF; this might be attributed to the $0.61 \mathrm{eV}$ magnitude of the $\mathrm{CdTe} / \mathrm{ZnTe}$ conduction-band offset $\left(\Delta E_{C}\right)$. Cell with $\mathrm{Cu}_{2} \mathrm{Te}$ BSR layer presents lower $J_{\text {sc }}$ because it has a spike on the valence band which produces high series resistance for majority carriers of the cell. On the other hand, in the case of $\mathrm{p}^{+}-\mathrm{CdTe}$ BSR layer, the absence of this spike and the weak magnitude of the $\mathrm{CdTe} / \mathrm{p}^{+}-\mathrm{CdTe}$ conduction-band offset $\left(\Delta E_{C}\right)$ increase the short circuit current slightly.

\section{Symbols}

$\varepsilon: \quad$ Dielectric permittivity

$\psi: \quad$ Electrostatic potential

$q$ : Elementary charge

$n, p$ : Concentration of electron and hole

$N_{D}: \quad$ Donor concentration

$N_{A}$ : Acceptor concentration

$\rho_{\text {def }}: \quad$ Charge density in defects

$J_{n}, J_{p}$ : Current density for electron and hole

$U_{n}, U_{p}$ : Carrier recombination rate of electron and hole

$G_{n}, G_{p}$ : Carrier generation rate of electron and hole

$\Delta E_{C}: \quad$ Conduction-band offset

$x: \quad$ Atomic composition (level of intermixing), taken in this work at the equilibrium value of 0.12 .

\section{Conflict of Interests}

The authors declare that there is no conflict of interests regarding the publication of this paper. 


\section{Acknowledgment}

The authors acknowledge the use of SCAPS-1D program developed by Marc Burgelman and colleagues at the University of Gent in all the simulations reported in this work.

\section{References}

[1] M. S. Hossain, N. Amin, M. A. Matin, M. M. Aliyu, T. Razykov, and K. Sopian, "A numerical study on the prospects of high efficiency ultra-thin $\mathrm{Zn}_{x} \mathrm{Cd}_{1-x} \mathrm{~S} / \mathrm{CdTe}$ solar cell," Chalcogenide Letters, vol. 8, no. 3, pp. 263-272, 2011.

[2] X. Wu, "High-efficiency polycrystalline CdTe thin-film solar cells," Solar Energy, vol. 77, no. 6, pp. 803-814, 2004.

[3] T. Carlsson and A. Brinkman, "Identification of degradation mechanisms in field-tested CdTe modules," Progress in Photovoltaics: Research and Applications, vol. 14, no. 3, pp. 213-224, 2006.

[4] M. A. Islam, Y. Sulaiman, and N. Amin, "A comparative study of BSF layers for ultra-thin CdS: O/CdTe solar cells," Chalcogenide Letters, vol. 8, no. 2, pp. 65-75, 2011.

[5] M. A. Green, K. Emery, Y. Hishikawa, W. Warta, and E. D. Dunlop, "Solar cell efficiency tables (version 43)," Progress in Photovoltaics: Research and Applications, vol. 22, no. 1, pp. 1-9, 2014.

[6] M. Gloeckler, A. L. Fahrenbruch, and J. R. Sites, "Numerical modeling of CIGS and CdTe solar cells: setting the baseline," in Proceedings of the 3rd World Conference on Photovoltaic Energy Conversion, vol. 1, pp. 491-494, Osaka, Japan, May 2003.

[7] I. Clemminck, M. Burgelman, M. Casteleyn, J. de Poorter, and A. Vervaet, "Interdiffusion of CdS and CdTe in screenprinted and sintered Cds-CdTe solar cells," in Proceedings of the Conference Record of the Twenty Second IEEE Photovoltaic Specialists Conference, pp. 1114-1119, Las Vegas, Nev, USA, October 1991.

[8] N. Amin, M. A. Matin, M. M. Aliyu, M. A. Alghoul, M. R. Karim, and K. Sopian, "Prospects of back surface field effect in ultra-thin high-efficiency CdS/CdTe solar cells from numerical modeling," International Journal of Photoenergy, vol. 2010, Article ID 578580, 8 pages, 2010.

[9] M. Burgelman, P. Nollet, and S. Degrave, "Modelling polycrystalline semiconductor solar cells," Thin Solid Films, vol. 361, pp. 527-532, 2000.

[10] N. Alex, M. Burgelman, D. Stefaan, V. Johan, and D. Koen, SCAPS Manual, Version 24, 2012.

[11] A. Islam, M. A. Matin, M. M. Aliyu, Y. Sulaiman, and N. Amin, "A numerical analysis on CdS:O window layer for higher efficiency cdte solar cells," in Proceedings of the 1st International Conference on the Developments in Renewable Energy Technology (ICDRET '09), pp. 181-184, Dhaka, Bangladesh, December 2009.

[12] M. A. Matin, N. Amin, A. Zaharim, and K. Sopian, "Ultrathin high efficiency CdS/CdTe thin film solar cells from numerical analysis," in Proceedings of the 8th WSEAS International Conference on Nonlinear Analysis, Nonlinear Systems and Chaos (NOLASC '09), pp. 338-344, La Laguna, Spain, July 2009.

[13] M. D. G. Potter, D. P. Halliday, M. Cousins, and K. Durose, "A study of the effects of varying cadmium chloride treatment on the luminescent properties of CdTe/CdS thin film solar cells," Thin Solid Films, vol. 361-362, pp. 248-252, 2000.

[14] N. Amin, K. Sopian, and M. Konagai, "Numerical modeling of $\mathrm{CdS} / \mathrm{CdTe}$ and CdS/CdTe/ZnTe solar cells as a function of CdTe thickness," Solar Energy Materials and Solar Cells, vol. 91, no. 13, pp. 1202-1208, 2007.
[15] P. Chelvanathan, M. I. Hossain, and N. Amin, "Performance analysis of copper-indium-gallium-diselenide (CIGS) solar cells with various buffer layers by SCAPS," Current Applied Physics, vol. 10, no. 3, pp. S387-S391, 2010.

[16] M. A. Matin, M. U. Tomal, A. M. Robin, and N. Amin, "Numerical analysis of novel back surface field for high efficiency ultrathin CdTe solar cells," International Journal of Photoenergy, vol. 2013, Article ID 652695, 8 pages, 2013.

[17] H. Fardi and F. Buny, "Characterization and modeling of $\mathrm{CdS} / \mathrm{CdTe}$ heterojunction thin-film solar cell for high efficiency performance," International Journal of Photoenergy, vol. 2013, Article ID 576952, 6 pages, 2013.

[18] J. Sites and J. Pan, "Strategies to increase CdTe solar-cell voltage," Thin Solid Films, vol. 515, no. 15, pp. 6099-6102, 2007.

[19] A. Morales-Acevedo, "Design of very thin CdTe solar cells with high efficiency," Energy Procedia, vol. 57, pp. 3051-3057, 2014. 

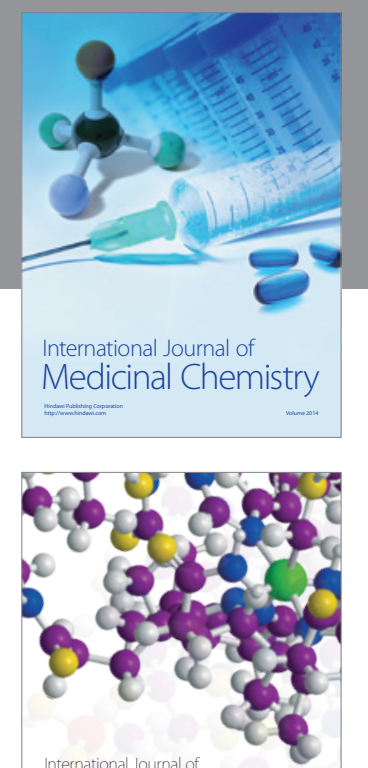

\section{Carbohydrate} Chemistry

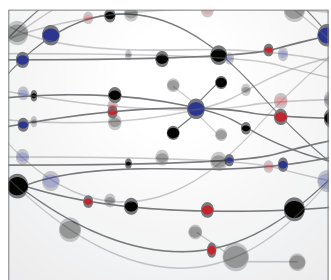

The Scientific World Journal
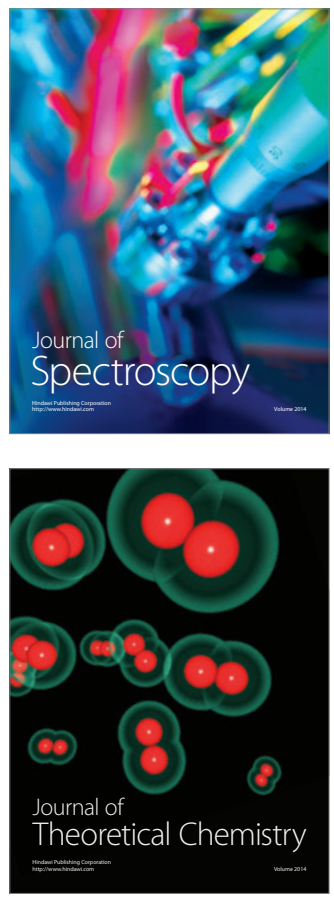
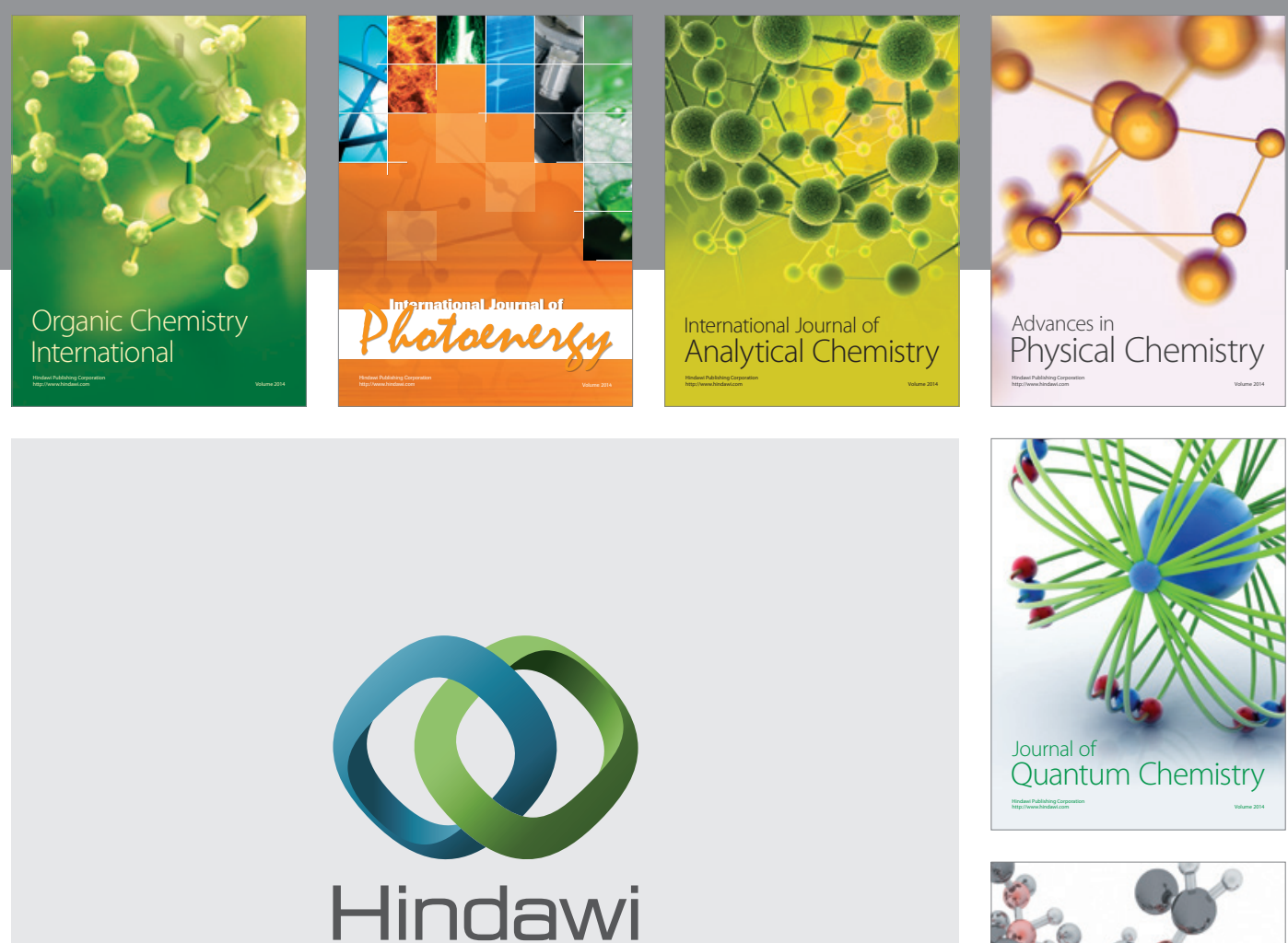

Submit your manuscripts at

http://www.hindawi.com

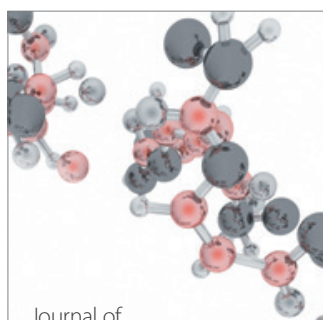

Analytical Methods

in Chemistry

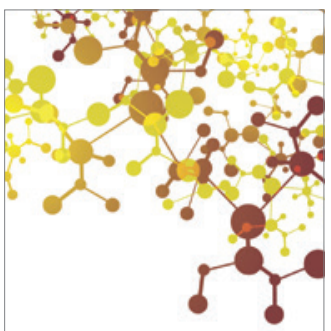

Journal of

Applied Chemistry

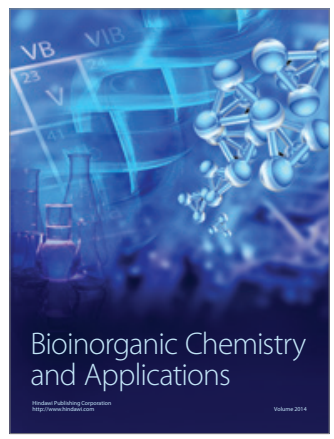

Inorganic Chemistry
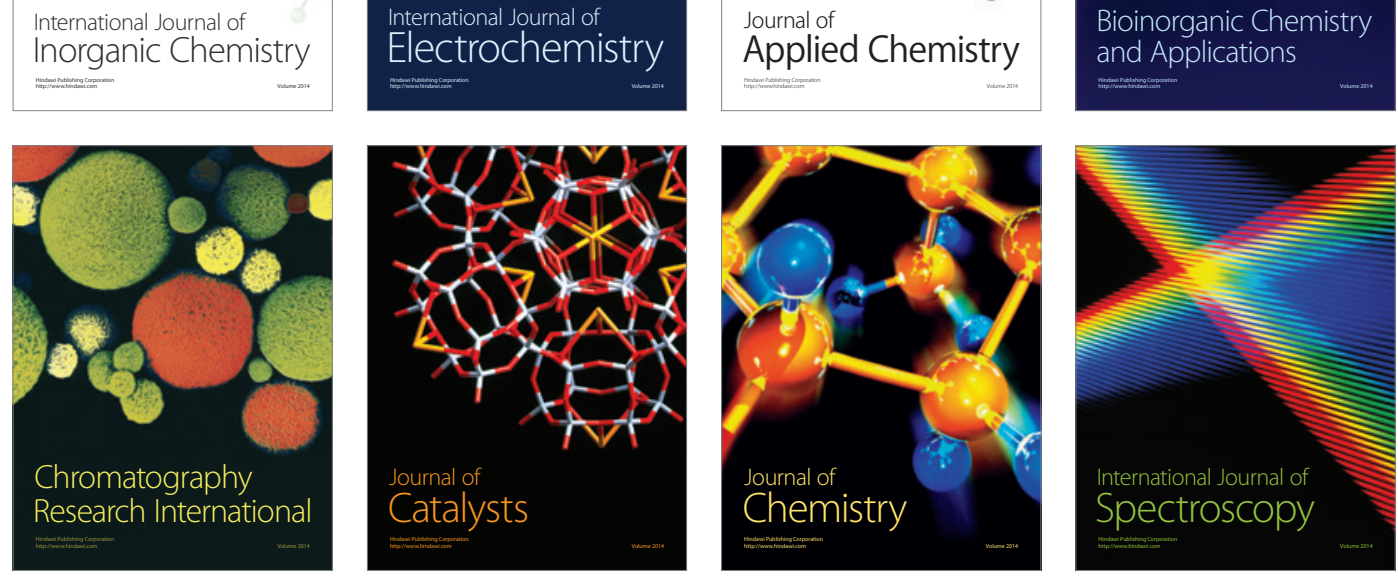